\title{
Inflammation, Cerebral Vasospasm, and Evolving Theories of Delayed Cerebral Ischemia
}

\author{
Kevin R. Carr, ${ }^{1}$ Scott L. Zuckerman, ${ }^{2}$ and J Mocco ${ }^{2}$ \\ ${ }^{1}$ Department of Neurological Surgery, University of Texas Health Sciences Center at San Antonio, San Antonio, TX 78229, USA \\ ${ }^{2}$ Department of Neurological Surgery, Vanderbilt University School of Medicine, Nashville, TN 37212, USA
}

Correspondence should be addressed to J Mocco; j.mocco@vanderbilt.edu

Received 7 November 2012; Revised 26 June 2013; Accepted 26 June 2013

Academic Editor: Mamede de Carvalho

Copyright ( $) 2013$ Kevin R. Carr et al. This is an open access article distributed under the Creative Commons Attribution License, which permits unrestricted use, distribution, and reproduction in any medium, provided the original work is properly cited.

\begin{abstract}
Cerebral vasospasm (CVS) is a potentially lethal complication of aneurysmal subarachnoid hemorrhage (aSAH). Recently, the symptomatic presentation of CVS has been termed delayed cerebral ischemia (DCI), occurring as early as 3-4 days after the sentinel bleed. For the past 5-6 decades, scientific research has promulgated the theory that cerebral vasospasm plays a primary role in the pathology of DCI and subsequently delayed ischemic neurological decline (DIND). Approximately 70\% of patients develop CVS after aSAH with $50 \%$ long-term morbidity rates. The exact etiology of CVS is unknown; however, a well-described theory involves an antecedent inflammatory cascade with alterations of intracellular calcium dynamics and nitric oxide fluxes, though the intricacies of this inflammatory theory are currently unknown. Consequently, there have been few advances in the clinical treatment of this patient cohort, and morbidity remains high. Identification of intermediaries in the inflammatory cascade can provide insight into newer clinical interventions in the prevention and management of cerebral vasospasm and will hopefully prevent neurological decline. In this review, we discuss current theories implicating the inflammatory cascade in the development of CVS and potential treatment targets.
\end{abstract}

\section{Introduction}

Subarachnoid hemorrhage (SAH) is a devastating neurological insult that causes significant morbidity and mortality [1]. One of the greatest sources of this morbidity and mortality is cerebral vasospasm (CVS), leading to delayed cerebral ischemia (DCI) [2]. While angiographic vasospasm is thought to occur in approximately $70 \%$ of patients after aSAH, only $25 \%$ develop symptomatic CVS $[3,4]$. Morbidity remains high despite years of clinical and basic science research done on the topic, with approximately $50 \%$ infarction rates in affected patients $[5,6]$.

An antecedent inflammatory cascade is one of the many etiologies thought to be responsible for the development of CVS. Experimental studies have shown involvement of cytokines, cell adhesion molecules, and leukocytes, and early clinical studies have attempted to inhibit components of the inflammatory cascade to mitigate CVS [7-19]. Additionally, endothelin receptor activation, nitric oxide inhibition, thromboxane receptor modification, and many cell signaling cascades are thought to play an integral role in the development of this pathology [20-27]. Currently, the primary treatment for this patient population involves hemodynamic augmentation and medically or surgically mediated intraarterial vasodilation. These treatments, while providing amelioration in the short term, have proved relatively ineffective in staving off neurological decline, in part due to lack of large scale analyses $[1,28]$. In our review, we hope to summarize past and current research in the area of inflammation and the development of CVS. An appreciation of these key inflammatory intermediaries will allow for the development of clinically significant interventions in this patient population.

\section{Clinical Diagnosis of CVS}

In patients with aSAH, neurological dysfunction presents within several hours after the injury. This decline was initially attributed to the progression of mass effect secondary to acute $\mathrm{SAH}$; however, current evidence suggests that an acute brain injury with subsequent cerebral ischemia plays a primary 
role. It is thought that the introduction of blood products, specifically hemoglobin, into the extravascular space initiates narrowing of the arterial vasculature within several hours [29], starting at approximately three days after-injury and lasting up to several weeks [30]. The arterial vasculature demonstrates diffuse or focal stenosis with significant restriction of blood flow visualized via angiography. CVS presents with focal neurological dysfunction and can precipitate the development of permanent ischemia in approximately 50\% of patients with CVS [2].

The gold standard for the diagnosis of CVS is angiography, specifically with digital subtraction angiography (DSA) [31]. As an improvement to the technique described by Ecker and colleagues in 1951 [32], DSA allows for high quality angiographic images via the digital subtraction of extraneous artifact [33]. In its use as a diagnostic tool, mild vasospasm is defined by less than $25 \%$ reduction in vessel patency. A greater than 50\% reduction is termed severe vasospasm [34]. Many authors have since espoused the utility of CTA and MRA as alternatives to the invasive techniques used in DSA [35-37]. In addition to being less invasive and severalfold faster than conventional angiography, CTA and MRA produce images of higher resolution than their predecessor $[38,39]$. These techniques however rely heavily on digital reconstruction, and their accuracies vary depending on the vascular territory assessed and operator experience $[31,35,39,40]$.

Transcranial Doppler sonography (TCD) is currently the primary tool used in the noninvasive diagnosis of cerebral vasospasm. Its use was first described in 1981 when Dalessandri et al. demonstrated efficacy in the visualization of cerebral blood flow in cerebral arteries [41]. It is currently the single most important noninvasive measure of cerebral vasospasm $[42,43]$. When vasospasm induces a decrease in arterial diameter, cerebral blood flow $(\mathrm{CBF})$ velocity concomitantly increases. CVS is most times described when $\mathrm{CBF}$ velocity exceeds $120 \mathrm{~cm} / \mathrm{s}[44,45]$. An increased ratio of $\mathrm{CBF}$ velocity between intracranial vessels, the middle cerebral artery (MCA) or anterior cerebral artery (ACA), and an extracranial ICA can be used to indicate CVS. This value is known as the Lindegaard index and is widely used today [46]. Most institutions identify clinical vasospasm as a ratio above $3: 1$. The diagnostic reliability of TCD has historically been called into question since factors such as the arterial window analyzed, patient movement, and operator experience affect the reliability of the test $[31,43,47]$. Specifically, changes in systemic pressure, cardiac output, and other factors that affect hemodynamic homeostasis can adversely affect reliability of the tool due to its strong dependence on cerebral blood flow dynamics [48]. In a comparative study between TCD and DSA in the assessment of aneurysmal vasospasm, Okada and colleagues highlighted the poor sensitivity of TCD for detecting vasospasm and noted that DSA was distinctly superior as a diagnostic tool [47]. Other studies have underscored the incongruences in the diagnostic sensitivity of this tool $[49,50]$. Tools such as jugular venous oxygen saturation monitoring, Xe-enhanced CT, positron emission tomography (PET), single photon emission CT (SPECT), and magnetic resonance imaging have also been used to diagnose CVS with varying sensitivities [51].

\section{CVS and Inflammation}

3.1. History. The earliest correlation between CVS and inflammation was established over 60 years ago. Walton in 1955 demonstrated that febrile patients who presented with SAHs fared worse than their afebrile counterparts [52]. Several decades later, studies by Rousseaux et al. confirmed a definitive relationship between the occurrence of symptomatic CVS and fever in affected patients (Table 1) [53]. It was in the late 1980's however that Spallone and colleagues demonstrated that leukocytosis, the sentinel indicator of systemic inflammation, was significantly higher in patients with aSAH [54]. These discoveries spurred interest in the role of the inflammatory response as a causative factor in the development of the pathology. Later studies substantiated these earlier findings, and additional inflammatory markers and cytokines were identified to play a pivotal role in the inflammatory process (Table 1).

3.2. The Inflammatory Cascade and CVS. As a result of decades of research into the inflammatory mediators of CVS, several theories explaining the pathophysiology have been proposed. One such theory states that the extravasation of erythrocytes into the cerebral parenchyma acts as the nidus for the vasospasms that characterize acute and chronic CVS [11, 18, 55, 56]. Extracorpuscular hemoglobin ( $\mathrm{Hb})$ is a proinflammatory moiety as opposed to its intravascular homolog [57-60]. The presence of $\mathrm{Hb}$ in the extravascular space liberates reactive oxygen species (ROS) that result in the peroxidation of membrane lipids of endothelial cells and proliferation of smooth muscle $[61,62]$. It is also thought that these oxidative stressors inhibit bradykinin mediated vascular relaxation after aSAH [63]. Additionally, it has been hypothesized that the presence of subarachnoid blood is a potent stimulant for nuclear factor-kappa B (NF- $\kappa \mathrm{B})$ mediated cytokine release augmenting the inflammatory reaction [11, 64]. Normally, once erythrocytes have entered the extravascular space, exposed $\mathrm{Hb}$ is rapidly bound to a hepatically produced haptoglobin (HP). HP exists in two isoforms, HP 1-1 and HP 2-2 of which HP 2-2 is thought to bind with less affinity and as such is relatively pro-inflammatory in comparison to its analog $[23,27,56,65]$. Macrocytes phagocytize $\mathrm{Hb}$ bound moieties and remove them from the extravascular space. The initial pro-inflammatory effect elicited by $\mathrm{Hb}$ and $\mathrm{Hb}$ bound moieties initiates an inflammatory cascade involving an increase of cytokines, leukocytes, and cell adhesion molecules (CAMs) characterizing the inflammatory process $[7,13,18,56,66,67]$.

The elevation in inflammatory cytokines and cell adhesion markers promotes the initial margination of leukocytes by CAMs on the endothelial surface. Of these cell adhesion markers, selectins (L-, P-) are most important in the initial capture $[9,20,68-71]$. Secondly, leukocyte rolling is facilitated by P- and E-selectins in which captured leukocytes are sequentially bound and released by adjacent CAMs. The end result is a sequential transmigration of leukocytes down a chemoattractant concentration gradient to the site of inflammation. Finally, firm adhesion to the endothelium effectively halts leukocyte rolling and promotes leukocyte diapedesis 
TABLE 1: Landmark discoveries of the relationship between vasospasm and inflammation in the last halfcentury.

History of the relationship between inflammatory markers and cerebral vasospasm: a look at contributions to the literature

\begin{tabular}{|c|c|c|c|}
\hline Author (year) & Inflammatory parameter assessed & Model & Findings \\
\hline Walton (1955) [52] & Fever & Human & SAH patients with fever have decreased survival \\
\hline $\begin{array}{l}\text { Rousseaux et al. (1980) } \\
\text { [53] }\end{array}$ & Fever & Human & SAH patients with fever have decreased survival \\
\hline Spallone et al. (1987) [54] & Leukocytosis & Human & SAH is accompanied by leukocytosis \\
\hline $\begin{array}{l}\text { Mathiesen et al. (1990) } \\
\text { [137] }\end{array}$ & Neopterin & Human & CSF neopterin levels rise with SAH \\
\hline Minami et al. (1991) [103] & LTC4 & Canine & LTC4 expression increases with SAH \\
\hline Peterson et al. (1990) [138] & Cell free blood components & Canine & $\begin{array}{l}\text { Subarachnoid foreign bodies induce angiographic BA } \\
\text { vasospasm }\end{array}$ \\
\hline Edwards et al. (1992) [57] & EDRF & Porcine & Adventitial hemoglobin reduces EDRF concentrations \\
\hline Onda et al. (1999) [139] & $\begin{array}{l}\text { MCP-1, cystatin B, inter-alpha-trypsin } \\
\text { inhibitor, serum amyloid A protein, and } \\
\text { GP130 }\end{array}$ & Canine & $\begin{array}{l}\text { SAH increases expression of inflammatory markers } \\
\text { genes }\end{array}$ \\
\hline Fabender et al., (2000) [9] & ET1, IL-6, and TNF $\alpha$ & In vitro & $\begin{array}{l}\text { Leukocytes activated by incubation with blood release } \\
\text { inflammatory markers }\end{array}$ \\
\hline Aihara et al. (2001) [140] & $\begin{array}{l}\text { Il-1A, Il-6, Il-6, Il10, VCAM-1, TGF-ss, } \\
\text { and bFGF }\end{array}$ & Canine & $\begin{array}{l}\text { SAH increases expression of markers with BA } \\
\text { vasospasm }\end{array}$ \\
\hline McGirt et al. (2002) [141] & MM-9, VEGF, and vWF & Human & $\begin{array}{l}\text { Increases in VEGF, MMP-9, and VEGF precede } \\
\text { angiographic vasospasm }\end{array}$ \\
\hline Sasaki et al. (2004) [142] & IL-1a, IL-1b, and IL-8 & Canine & $\begin{array}{l}\text { Hemolysate increased inflammatory marker expression } \\
\text { by MAPK mediated pathways }\end{array}$ \\
\hline Recinos et al. (2006) [19] & LPS & Leporine & LPS induces BA narrowing and clinical CVS \\
\hline Zhou et al. (2007) [143] & $\mathrm{TNF} \alpha, \mathrm{ICAM}-1$, and MPO & Leporine & $\begin{array}{l}\text { Hemolysate increases NF-Kb DNA binding activity } \\
\text { with increase in inflammatory markers and } \\
\text { angiographic BA vasospasm }\end{array}$ \\
\hline $\begin{array}{l}\text { Jędrzejowska-Szypułka et } \\
\text { al. (2009) [68] }\end{array}$ & IL-1B & Murine & $\begin{array}{l}\text { IL-1B activity increased with hemolysate and reversed } \\
\text { with IL-1B antibodies }\end{array}$ \\
\hline Wang et al. (2010) [144] & CD34 & Murine & $\begin{array}{l}\text { CD34 expression increases with SAH at the peak of } \\
\text { vasospasm }\end{array}$ \\
\hline Wirrig et al. (2011) [145] & SPC & Murine & $\begin{array}{l}\text { SPC increases MCP- } 1 \text { and acts as inflammatory } \\
\text { mediator in CVS }\end{array}$ \\
\hline
\end{tabular}

LTC4: leukotriene C4, MCP-1: monocyte chemotactic protein 1, ET1: endothelin 1, TNF $\alpha$ : tumor necrosis factor alpha, MMP9: matrix metalloproteinase, bFGF: basic fibroblast growth factor, EDRF: endothelium derived relaxing factor, IL1: interleukin 1, LPS: lipopolysaccharide, ICAM-1: intercellular adhesion molecule 1, MPO: myeloperoxidase, vWF: von Willebrand's factor, CD34: cluster of differentiation 34, SPC: sphyngosylphosphorylcholine, BA: basilar artery, and GP130: glycoprotein 130 .

$[11,72]$. This process is mediated by another class of CAMs, the integrins of which CAM-1, LFA-1 and other moieties play vital roles. Immunoglobulins ICAM-1, and VCAM-1 are also required for adhesion [73-75]. Experimental models have successfully demonstrated the temporal relationship between the initial inciting injury and increases in cytokine concentrations [76-78]. Of particular interest are IL- $1 \beta$, IL6 , TL-8, and TNF- $\alpha$. In various studies, increases in the intraventricular concentrations of these moieties have been demonstrated to occur after injury [79-81]. Though the CSF concentrations of these inflammatory intermediaries increase after-hemorrhage, the change in serum concentrations is not as reliable. In fact, studies have demonstrated both elevations [82] and no relevant changes [76] in the analysis of systemic concentration of these cytokines. It is irrefutable, however, that leukocytosis and changes in C-reactive protein levels
(CRP) correlate strongly with clinical outcomes after-injury $[83,84]$.

Transendothelial migration, or diapedesis, is the final step in the recruitment of inflammatory leukocytes and encompasses a multitude of cell adhesion molecules and intracellular cell signaling pathways [72]. Macrophages, monocytes and neutrophils are the primary cells implicated in the initial stages of injury and have been found in postinjury histological analysis to be a highly represented cell type in adjacent tissue $[85,86]$. These inflammatory cells mediate macrocytosis of free erythrocytes as part of their natural function; however, after aSAH there is a disruption of normal cerebral blood flow preventing the re-entry of macrophages and leukocytes into circulation. This results in the degradation and degranulation of these cells in the parenchymal space. Ultimately, a release of inflammatory cytokines and 
other vasoactive compounds, which characterize the chronic vasospasm of CVS, is thought to occur approximately four days after injury [18].

In the final analysis, the upregulation of ET-1, destructive free radicals, $\mathrm{NO}$ dysregulation, and spasmodic cytokines are all thought to play a substantial role in the onset of vasospasm [1, 87-89]. ET-1 itself is a potent vasoconstrictor whose upregulation peaks 3-4 days after injury [90]. It is thought to be increased due to cerebral ischemia and other stressors with possible augmentation by the aforementioned antecedent inflammatory cascade. Its effect on vasoconstriction is multifaceted $[91,92]$. Through a negative feedback loop, its activation of endothelial nitric oxide synthetase (NOs) depletes NO concentrations [93]. NO plays a significant role in vascular tone through the inhibition of calcium production and subsequent reduction in contractile forces; thus, its inhibition leads to vessel narrowing [94]. Additionally, ET-1 is also integral to fibrosis, tissue growth, and inflammation [26, 92, 95]. In summary, through several distinct mechanisms, the inflammatory changes surrounding SAH lead to global stenosis of cerebral vasculature [26, 96-99].

\subsection{Research Findings Relating Inflammation to CVS.} Research has focused on modifying several inflammatory markers (Table 2). Several clinical trials have either corroborated or refuted the clinical efficacy of the suggested treatments [1]. Anti-inflammatory agents such as dexamethasone and cyclosporine A (Cys-A) have shown favorable improvements in experimental models $[100,101]$. However, other known agents, such as tacrolimus, an inhibitor of T-cell maturation similar to Cys-A, have not shown similar results [102]. There are also studies implicating the complement system, the 3-hydroxy-3-methyl-glutaryl coenzyme A (HMG-CoA) reductase pathway, and multiple other systems; however, results even in the experimental stages have been varied [103-106].

There have been experimental reports documenting improvement in CVS using various pharmaceutical agents, however, the variety of these treatments is sparse (Table 3 ). In 2011, Velat and colleagues reviewed 44 randomized control trials (RCT) and 9 meta-analyses on vasospasm after SAH [1]. Their studies suggested that only oral nimodipine was efficacious in stymieing CVS with improvement in neurological decline after SAH. In an experimental murine model of cerebral vasospasm, Bowman and colleagues demonstrated a statistically significant dose dependent reduction in vasospasm after administration of a polyclonal antibody targeted against IL-6 $(P<0.05)$ [107]. Such findings indicate that cytokine upregulation is antecedent to radiographic vasospasm, and their attenuation may minimize vessel narrowing. The propensity for magnesium supplementation to mitigate CVS has also been widely studied [108-113]. In fact, a small Swiss study in 2012 suggested that high dose magnesium administration compared to low dosage suppressed postSAH increases in IL-6 $(P=0.021)$ and IL-1 $\beta(P<0.001)$, respectively [78].
Agents such as organic stress reducers including trehalose modulate the effect of the cyclooxygenase-2 (COX-2) catalytic pathway [20]. In experimental murine models, the polysaccharide reduced concentrations of pro-inflammatory markers leading to a reversal of SAH induced vasospasm. Of the multiple markers that trehalose modulates is endothelin1 , which modulates vasoconstriction [91, 92], via its effects on nitric oxide, fibrosis, tissue growth, and inflammation [92]. Consequently, it has been the target of major studies on the treatment of vasospasm [114]. The reduction in plasma arachidonic acid is also thought to mediate these experimental findings. Molecular hydrogen has been found to be useful experimentally to decrease vasospasm and peroxidation [115]. These evidences along with other recent experimental findings suggest a multifactorial process that precedes CVS and clinical neurological dysfunction, which may or may not be directly related.

Myeloperoxidase (MPO), a marker of inflammation in coronary artery disease, is thought to be implicated in the inflammatory process of CVS [116]. MPO is a lysosomal enzyme that is a component of the respiratory burst in leukocyte antibacterial function. The enzyme catalyzes the production of hypohalous acids like hypoclorous acid ( $\mathrm{HOCl})$, which modify cellular membranes [117]. In reports by Lim and colleagues, the biomarker demonstrated elevations in CSF concentrations that mirror the onset of CBF abnormalities in CVS, supporting MPO as a surrogate predictor of CVS after SAH. Because of to its role in inflammation, its upregulation is most likely related to antecedent leukocyte recruitment [116].

3.4. DCI Has an Evolving Pathophysiology. The mortality that ensues after CVS is often due to delayed cerebral ischemia (DCI). DCI is defined as new focal neurological deficits (symptomatic vasospasm) or ischemic focus in the setting of radiographic vasospasm [118]. While the relationship between inflammation and CVS is irrefutable, it is unlikely to be the single perpetrator behind delayed cerebral ischemia (DCI) and subsequent neurologic decline. Results from the CONSCIOUS trials assessed the effects of the endothelin1 receptor antagonist Clazosentan after $\mathrm{SAH}$, and while there was significant improvement in angiographic CVS, neurological dysfunction was only minimally affected [119]. Hansen-Schwartz and colleagues concluded that these results point to a more extensive implication of inflammation in the pathophysiology of post-SAH neurological dysfunction. Hansen-Schwartz also argued that the lack of temporal alignment between angiographic CVS and DCI symptoms suggest the need for further studies [120].

Cortical spreading depolarization (CSD), intravascular microthrombosis, and early brain injury have all received traction in the field as alternate theories of CVS [120-124]. In the immediate posthemorrhage period, rapid increases in cerebral edema [125], ICP [126, 127], and changes in cerebral autoregulation [128] are all thought to disrupt the homeostatic milieu resulting in early brain injury. This injury fosters an environment for cerebral ischemia with altered perfusion and hypoxia. Transient and sporadic neuroelectrical 
TABLE 2: Early studies report improvement in experimental proxies of CVS in various models.

\begin{tabular}{|c|c|c|c|}
\hline \multicolumn{4}{|c|}{ Studies involving modifications of the inflammatory process with effects on CVS } \\
\hline Author (year) & Parameter assessed & Model & Findings \\
\hline $\begin{array}{l}\text { Tokiyoshi et al. (1991) } \\
{[146]}\end{array}$ & Symptomatic vasospasm & Human & $\begin{array}{l}\text { TXA2 synthetase inhibition decreased } \\
\text { symptomatic vasospasm }\end{array}$ \\
\hline Lin et al. (2005) [67] & ACA diameter & Murine & $\begin{array}{l}\text { Anti-E selectin mAb prevents SAH induced } \\
\text { angiographic vasospasm }\end{array}$ \\
\hline $\begin{array}{l}\text { Fei and Golwa (2007) } \\
{[101]}\end{array}$ & MCA velocity & Human & $\begin{array}{l}\text { Topical dexamethasone prevents } \\
\text { angiographic vasospasm }\end{array}$ \\
\hline Iseda et al. (2007) [147] & BA diameter, IL-1B & Leporine & $\begin{array}{l}\text { Caspase inhibitor (Z-VAD-FMK) decreased } \\
\text { angiographic BA vasospasm and IL-1B levels }\end{array}$ \\
\hline Lin et al. (2007) [66] & ICAM-1, BA diameter & Leporine & $\begin{array}{l}\text { Endothelin converting enzyme inhibitor } \\
\text { (CGS 26303) decreases ICAM-1 levels and } \\
\text { BA vasospasm }\end{array}$ \\
\hline Chen et al. (2008) [69] & JAK2 & Leporine & $\begin{array}{l}\text { JAK2 inhibitor (AG490) decreases JAK2 } \\
\text { activation and angiographic BA vasospasm }\end{array}$ \\
\hline $\begin{array}{l}\text { Yoshimoto et al. (2009) } \\
\text { [148] }\end{array}$ & Angiography & Human & $\begin{array}{l}\text { Cilostazol prevents angiographic vasospasm } \\
\text { after SAH }\end{array}$ \\
\hline Wu et al. (2010) [149] & TLR4, TNF1 & In vitro & $\begin{array}{l}\text { PPAR gamma agonist decreases TLR } 4 \\
\text { expression and cytokine release }\end{array}$ \\
\hline Chang et al. (2010) [150] & $\begin{array}{l}\text { ICAM-1, VCAM-1, E-Selectin, and BA } \\
\text { diameter }\end{array}$ & Murine & $\begin{array}{l}\text { 6-MP decreases ICAM-1 and E-Selectin and } \\
\text { increases angiographic BA vasospasm after } \\
\text { SAH }\end{array}$ \\
\hline
\end{tabular}

TXA2: thromboxane A2, PAF: platelet activating factor, LFA-1: lymphocyte function associated antigen, NO: nitrous oxide, JNK: c-Jun N terminal kinase, mAb: monoclonal antibody, HMG-CoA: 3-hydroxy-3-methylglutaryl-coenzyme A, JAK2: Janus kinase 2, PDE: phosphodiesterase, 6-MP: 6-mercaptopurine, and PPAR gamma: peroxisome proliferator activated receptor gamma.

TABLE 3: Recent studies have shown improvements in clinical and experimental vasospasm with the use of other various pharmacological additives.

\begin{tabular}{|c|c|c|c|c|}
\hline \multicolumn{5}{|c|}{ Recent assessments of potential treatments for vasospasm after SAH } \\
\hline Author (year) & Intervention & Parameter altered/assessed & Model & Findings \\
\hline $\begin{array}{l}\text { Meyers and Connolly } \\
\text { (2011) [119] }\end{array}$ & $\begin{array}{l}\text { Endothelial receptor } \\
\text { antagonist }\end{array}$ & $\begin{array}{l}\text { Delayed ischemic } \\
\text { neurological decline }\end{array}$ & Human & $\begin{array}{l}\text { Endothelial receptor antagonists } \\
\text { (Clazosentan) have no effect on } \\
\text { vasospasm related morbidity and } \\
\text { mortality }\end{array}$ \\
\hline Fathi et al. (2011) [89] & Sodium nitrate & Arterial diameter & Primates & IV sodium nitrite reverses CVS after $\mathrm{SAH}$ \\
\hline $\begin{array}{l}\text { Muehlschlegel et al. (2011) } \\
\text { [151] }\end{array}$ & Dantrolene & TCD & Human & IV dantrolene decreases CBF after $\mathrm{SAH}$ \\
\hline Echigo et al. (2012) [20] & Trehalose & $\begin{array}{l}\text { NF-Kb, ET-1, COX-2, and } \\
\mathrm{NO}_{x}\end{array}$ & Leporine & $\begin{array}{l}\text { Trehalose decreases lipid peroxidation, } \\
\text { arachidonic acid release, vasospasm, and } \\
\text { inflammatory markers after SAH }\end{array}$ \\
\hline Hong et al. (2012) [115] & Hydrogen rich saline & $\begin{array}{l}\text { SOD, GPx, and } \\
\text { malondialdehyde }\end{array}$ & Murine & $\begin{array}{l}\text { Molecular hydrogen reduces } \\
\text { peroxidation and vasospasm after SAH }\end{array}$ \\
\hline Pradilla et al. (2012) [23] & L-Citrulline & $\begin{array}{l}\text { BA diameter, } \\
\text { neurobehaviour, and NOS } \\
\text { expression }\end{array}$ & Murine & $\begin{array}{l}\text { Systemic L-citrulline prevents } \\
\text { angiographic BA vasospasm and } \\
\text { improves neurobehaviour and NOS } \\
\text { expression after SAH }\end{array}$ \\
\hline Zhang et al. (2012) [152] & mTOR inhibition & $\begin{array}{l}\text { BA diameter, appetite, and } \\
\text { activity scores }\end{array}$ & Canine & $\begin{array}{l}\text { mTOR inhibitor (rapamycin) reduced } \\
\text { CVS after SAH }\end{array}$ \\
\hline
\end{tabular}

SOD: superoxide dismutase, CBF: cerebral blood flow, GPx: glutathione peroxidase, NOS: nitric oxide synthase, BA: basilar artery, mTOR: mammalian target of rapamycin, and TCD: transcranial Doppler. 
disruptions also occur in the injured brain after acute injury [129]. Through experimental murine models, researchers have demonstrated that these brief episodes of electrical dampening differentially affect cerebral perfusion resulting in either hyperperfusion or hypoperfusion. This hemodynamic imbalance propagates damage created during early brain injury [130]. Finally, correlations between elevated procoagulant factors and DCI occurrence have strongly suggested a role for microthrombosis in the pathophysiology [131]. The detection of microthrombi in postmortem analysis [132] and a $70 \%$ prevalence of microthrombi in SAH patients [133] also point to the involvement of the coagulation cascade in the development of DCI. It is now more likely that CVS is one of many factors that play some part in the neurological decline consistent with DCI.

3.5. New Research. Current clinical trials are investigating possible contributing factors antecedent to DCI and DIND. Most notably, the EARLYDRAIN and LUMAS trials evaluate early evacuation of CSF through a lumbar drain [134, 135]. The LUMAS trial evaluated 210 patients with aSAH and randomized 105 to receive standard therapy and a lumbar drain, with the remaining 105 randomized to the control group receiving only standard management. The authors found that lumbar drainage of CSF after aSAH was associated with reduced DIND and improved early clinical outcome but had no difference in outcomes at 6 months. Preliminary studies have also shown efficacy using a kinetic treatment, intrathecal thrombolytic therapy in conjunction with head shaking. In this small study, 9 patients were selected to receive multimodal treatment while 11 received standard therapy. After 14 days of observation, there was decreased DIND and vasospasm related infarct in the intrathecal thrombolytic therapy group compared to the control [136]. Lastly, the depolarizations in ischaemia after aneurysmal subarachnoid haemorrhage (DISCHARGE-1) trial are an ongoing multicenter diagnostic phase III study that assesses electrical depression of the cerebral cortex after aSAH. The aim is to calculate the sensitivity and specificity of the duration of cortical spreading depression as a proxy for DCI after aSAH. As we look to future research, it is hoped that these theories may become incorporated in to standard therapies for the treatment of CVS.

\section{Conclusion}

From all indications, one of the major limiting factors in the management of CVS is an understanding of the extent of early brain injury secondary to SAH. Various studies have proven the relationship between vasospasm and accompanying neurological decline. We are currently limited by the difficulty in consistently and accurately diagnosing and treating affected patients. It is unlikely that there will be a "silver bullet" treatment for CVS and DCI. The role of inflammation in CVS represents a possible mechanism behind the development of DCI after SAH, and targeting the inflammatory process has potential to significantly reduce CVS, though further studies are necessary. Cerebral vasospasm continues to be regarded

as an important factor in the progression to DCI in patients following SAH. It cannot be however regarded as the single factor behind the neurological decline in this patient cohort.

\author{
Abbreviations \\ CVS: \\ DCI: \\ DIND: \\ aSAH: \\ TBI: \\ CTA: \\ PET: \\ SPECT: \\ LTC4: \\ MCP1: \\ ET1: \\ TNF $\alpha$ : \\ MMP9: \\ bFGF: \\ EDRF: \\ IL1: \\ LPS: \\ ICAM-1: \\ MPO: \\ vWF: \\ CD34: \\ SPC: \\ BA: \\ GP130: \\ TXA2: \\ PAF: \\ LFA-1: \\ NO: \\ JNK: \\ $\mathrm{mAb}$ : \\ HMG-CoA: 3-Hydroxy-3-methylglutaryl-coenzyme \\ A \\ JAK2: $\quad$ Janus kinase 2 \\ PDE: $\quad$ Phosphodiesterase \\ 6-MP: 6-Mercaptopurine, \\ PPAR gamma: Peroxisome proliferator activated \\ receptor gamma \\ SOD: Superoxide dismutase \\ CBF: Cerebral blood flow \\ GPx: Glutathione peroxidase \\ NOS: $\quad$ Nitric oxide synthase \\ BA: Basilar artery \\ mTOR: Mammalian target of rapamycin.
}

\section{Conflict of Interests}

There were no external sources of financial support for this paper. 


\section{Disclosure}

The authors report no conflict of interests concerning the materials or methods used in this study or the findings specified in this paper.

\section{References}

[1] G. J. Velat, M. M. Kimball, J Mocco, and B. L. Hoh, "Vasospasm after aneurysmal subarachnoid hemorrhage: review of randomized controlled trials and meta-analyses in the literature," World Neurosurgery, vol. 76, no. 5, pp. 446-454, 2011.

[2] M. R. Mayberg, H. H. Batjer, R. Dacey et al., "Guidelines for the management of aneurysmal subarachnoid hemorrhage: a statement for healthcare professionals from a special writing group of the Stroke Council, American Heart Association," Circulation, vol. 90, no. 5, pp. 2592-2605, 1994.

[3] N. F. Kassell, T. Sasaki, A. R. T. Colohan, and G. Nazar, "Cerebral vasospasm following aneurysmal subarachnoid hemorrhage," Stroke, vol. 16, no. 4, pp. 562-572, 1985.

[4] B. Weir, R. L. Macdonald, and M. Stoodley, "Etiology of cerebral vasospasm," Acta Neurochirurgica, Supplement, vol. 1999, no. 72, pp. 27-46, 1999.

[5] E. C. Haley Jr., N. F. Kassell, and J. C. Torner, “The international cooperative study on the timing of aneurysm surgery: the North American experience," Stroke, vol. 23, no. 2, pp. 205-214, 1992.

[6] M. R. Mayberg, H. H. Batjer, R. Dacey et al., "Guidelines for the management of aneurysmal subarachnoid hemorrhage: a statement for healthcare professionals from a special writing group of the Stroke Council, American Heart Association," Stroke, vol. 25, no. 11, pp. 2315-2328, 1994.

[7] M. Bavbek, R. Polin, A.-L. Kwan, A. S. Arthur, N. F. Kassell, and K. S. Lee, "Monoclonal antibodies against ICAM-1 and CD18 attenuate cerebral vasospasm after experimental subarachnoid hemorrhage in rabbits," Stroke, vol. 29, no. 9, pp. 1930-1935, 1998.

[8] Q.-A. Thai, E. M. Oshiro, and R. J. Tamargo, "Inhibition of experimental vasospasm in rats with the periadventitial administration of ibuprofen using controlled-release polymers," Stroke, vol. 30, no. 1, pp. 140-147, 1999.

[9] K. Fabender, B. Hodapp, S. Rossol et al., "Endothelin-1 in subarachnoid hemorrhage: an acute-phase reactant produced by cerebrospinal fluid leukocytes," Stroke, vol. 31, no. 12, pp. 2971-2975, 2000.

[10] R. E. Clatterbuck, P. Gailloud, L. Ogata et al., "Prevention of cerebral vasospasm by a humanized anti-CD11/CD18 monoclonal antibody administered after experimental subarachnoid hemorrhage in nonhuman primates," Journal of Neurosurgery, vol. 99, no. 2, pp. 376-382, 2003.

[11] A. S. Dumont, R. J. Dumont, M. M. Chow et al., "Cerebral vasospasm after subarachnoid hemorrhage: putative role of inflammation," Neurosurgery, vol. 53, no. 1, pp. 123-135, 2003.

[12] M. J. McGirt, J. C. Mavropoulos, L. Y. McGirt et al., "Leukocytosis as an independent risk factor for cerebral vasospasm following aneurysmal subarachnoid hemorrhage," Journal of Neurosurgery, vol. 98, no. 6, pp. 1222-1226, 2003.

[13] H. Ulbrich, E. E. Eriksson, and L. Lindbom, "Leukocyte and endothelial cell adhesion molecules as targets for therapeutic interventions in inflammatory disease," Trends in Pharmacological Sciences, vol. 24, no. 12, pp. 640-647, 2003.

[14] J. L. Frazier, G. Pradilla, P. P. Wang, and R. J. Tamargo, "Inhibition of cerebral vasospasm by intracranial delivery of ibuprofen from a controlled-release polymer in a rabbit model of subarachnoid hemorrhage," Journal of Neurosurgery, vol. 101, no. 1, pp. 93-98, 2004.

[15] G. Pradilla, P. P. Wang, F. G. Legnani, L. Ogata, G. N. Dietsch, and R. J. Tamargo, "Prevention of vasospasm by antiCD11/CD18 monoclonal antibody therapy following subarachnoid hemorrhage in rabbits," Journal of Neurosurgery, vol. 101, no. 1, pp. 88-92, 2004.

[16] T. Keiper, S. Santoso, P. P. Nawroth, V. Orlova, and T. Chavakis, "The role of junctional adhesion molecules in cell-cell interactions," Histology and Histopathology, vol. 20, no. 1, pp. 197-203, 2005.

[17] G. Pradilla, Q.-A. Thai, F. G. Legnani et al., "Local delivery of ibuprofen via controlled-release polymers prevents angiographic vasospasm in a monkey model of subarachnoid hemorrhage," Neurosurgery, vol. 57, no. 1, supplement, pp. S-184-S-189, 2005.

[18] G. L. Gallia and R. J. Tamargo, "Leukocyte-endothelial cell interactions in chronic vasospasm after subarachnoid hemorrhage," Neurological Research, vol. 28, no. 7, pp. 750-758, 2006.

[19] P. F. Recinos, G. Pradilla, Q.-A. Thai, M. Perez, A. M. Hdeib, and R. J. Tamargo, "Controlled release of lipopolysaccharide in the subarachnoid space of rabbits induces chronic vasospasm in the absence of blood," Surgical Neurology, vol. 66, no. 5, pp. 463-469, 2006.

[20] R. Echigo, N. Shimohata, K. Karatsu, F. Yano, Y. KayasugaKariya, A. Fujisawa et al., "Trehalose treatment suppresses inflammation, oxidative stress, and vasospasm induced by experimental subarachnoid hemorrhage," Journal of Translational Medicine, vol. 10, no. 1, p. 80, 2012.

[21] H. Takeuchi, M. Tanabe, H. Okamoto, and M. Yamazaki, "Effects of thromboxane synthetase inhibitor (RS-5186) on experimentally-induced cerebral vasospasm," Neurological Research, vol. 21, no. 5, pp. 513-516, 1999.

[22] V. D. Jadhav, A. Jabre, and T. J.-F. Lee, "Effect of phospholipase C blockade on cerebral vasospasm," Cerebrovascular Diseases, vol. 25, no. 4, pp. 362-365, 2008.

[23] G. Pradilla, T. Garzon-Muvdi, J. J. Ruzevick et al., "Systemic L-citrulline prevents cerebral vasospasm in haptoglobin 2-2 transgenic mice after subarachnoid hemorrhage," Neurosurgery, vol. 70, pp. 747-756, 2012.

[24] A. K. Vellimana, E. Milner, T. D. Azad et al., "Endothelial nitric oxide synthase mediates endogenous protection against subarachnoid hemorrhage-induced cerebral vasospasm," Stroke, vol. 42, no. 3, pp. 776-782, 2011.

[25] R. M. Pluta, "Delayed cerebral vasospasm and nitric oxide: review, new hypothesis, and proposed treatment," Pharmacology and Therapeutics, vol. 105, no. 1, pp. 23-56, 2005.

[26] A. Suhardja, "Mechanisms of disease: roles of nitric oxide and endothelin-1 in delayed cerebral vasospasm produced by aneurysmal subarachnoid hemorrhage," Nature Clinical Practice Cardiovascular Medicine, vol. 1, no. 2, pp. 110-116, 2004.

[27] E. N. Momin, K. E. Schwab, K. L. Chaichana, R. Miller-Lotan, A. P. Levy, and R. J. Tamargo, "Controlled delivery of nitric oxide inhibits leukocyte migration and prevents vasospasm in haptoglobin 2-2 mice after subarachnoid hemorrhage," Neurosurgery, vol. 65, no. 5, pp. 937-945, 2009.

[28] D. J. Capampangan, K. E. Wellik, M. I. Aguilar, B. M. Demaerschalk, and D. M. Wingerchuk, "Does prophylactic postoperative hypervolemic therapy prevent cerebral vasospasm and improve clinical outcome after aneurysmal subarachnoid hemorrhage?” Neurologist, vol. 14, no. 6, pp. 395-398, 2008. 
[29] P. Vorkapic, J. A. Bevan, and R. D. Bevan, "Longitudinal in vivo and in vitro time-course study of chronic cerebrovasospasm in the rabbit basilar artery," Neurosurgical Review, vol. 14, no. 3, pp. 215-219, 1991.

[30] B. Weir, M. Grace, J. Hansen, and C. Rothberg, "Time course of vasospasm in man," Journal of Neurosurgery, vol. 48, no. 2, pp. 173-178, 1978.

[31] J. N. Mills, V. Mehta, J. Russin, A. P. Amar, A. Rajamohan, and W. J. Mack, "Advanced imaging modalities in the detection of cerebral vasospasm," Neurology Research International, vol. 2013, Article ID 415960, 15 pages, 2013.

[32] A. Ecker and P. A. Riemenschneider, "Arteriographic demonstration of spasm of the intracranial arteries, with special reference to saccular arterial aneurysms," Journal of Neurosurgery, vol. 8, no. 6, pp. 660-667, 1951.

[33] E. A. Perez-Arjona, Z. Delproposto, V. Sehgal, and R. D. Fessler, "New techniques in cerebral imaging," Neurological Research, vol. 24, supplement 1, pp. S17-S26, 2002.

[34] N. Janjua and S. A. Mayer, "Cerebral vasospasm after subarachnoid hemorrhage," Current Opinion in Critical Care, vol. 9, no. 2, pp. 113-119, 2003.

[35] E. D. Greenberg, R. Gold, M. Reichman et al., "Diagnostic accuracy of CT angiography and CT perfusion for cerebral vasospasm: a meta-analysis," American Journal of Neuroradiology, vol. 31, no. 10, pp. 1853-1860, 2010.

[36] A. R. Dehdashti, D. A. Rufenacht, J. Delavelle, A. Reverdin, and N. De Tribolet, "Therapeutic decision and management of aneurysmal subarachnoid haemorrhage based on computed tomographic angiography," British Journal of Neurosurgery, vol. 17, no. 1, pp. 46-53, 2003.

[37] G. B. Anderson, J. M. Findlay, D. E. Steinke, and R. Ashforth, "Experience with computed tomographic angiography for the detection of intracranial aneurysms in the setting of acute subarachnoid hemorrhage," Neurosurgery, vol. 41, no. 3, pp. 522-528, 1997.

[38] F. Chen, X. Wang, and B. Wu, "Neuroimaging research on cerebrovascular spasm and its current progress," Acta Neurochirurgica. Supplement, vol. 110, no. 2, pp. 233-237, 2011.

[39] S. Tamatani, O. Sasaki, S. Takeuchi, Y. Fujii, T. Koike, and R. Tanaka, "Detection of delayed cerebral vasospasm, after rupture of intracranial aneurysms, by magnetic resonance angiography," Neurosurgery, vol. 40, no. 4, pp. 748-754, 1997.

[40] C. B. Grandin, G. Cosnard, F. Hammer, T. P. Duprez, G. Stroobandt, and P. Mathurin, "Vasospasm after subarachnoid hemorrhage: diagnosis with MR angiography," American Journal of Neuroradiology, vol. 21, no. 9, pp. 1611-1617, 2000.

[41] K. Dalessandri, J. N. St. John, and S. N. Carson, "Correction and monitoring of postoperative cerebral vasospasm," Angiology, vol. 32, no. 3, pp. 212-216, 1981.

[42] R. Aaslid, T. M. Markwalder, and H. Nornes, "Noninvasive transcranial Doppler ultrasound recording of flow velocity in basal cerebral arteries," Journal of Neurosurgery, vol. 57, no. 6, pp. 769-774, 1982.

[43] J. I. Suarez, A. I. Qureshi, A. B. Yahia et al., "Symptomatic vasospasm diagnosis after subarachnoid hemorrhage: evaluation of transcranial Doppler ultrasound and cerebral angiography as related to compromised vascular distribution," Critical Care Medicine, vol. 30, no. 6, pp. 1348-1355, 2002.

[44] C. M. Burch, M. A. Wozniak, M. A. Sloan et al., "Detection of intracranial internal carotid artery and middle cerebral artery vasospasm following subarachnoid hemorrhage," Journal of Neuroimaging, vol. 6, no. 1, pp. 8-15, 1996.
[45] M. A. Wozniak, M. A. Sloan, M. I. Rothman et al., "Detection of vasospasm by transcranial Doppler sonography: the challenges of the anterior and posterior cerebral arteries," Journal of Neuroimaging, vol. 6, no. 2, pp. 87-93, 1996.

[46] K. F. Lindegaard, H. Nornes, S. J. Bakke, W. Sorteberg, and P. Nakstad, "Cerebral vasospasm after subarachnoid haemorrhage investigated by means of transcranial Doppler ultrasound," Acta Neurochirurgica, Supplement, vol. 42, pp. 81-84, 1988.

[47] Y. Okada, T. Shima, M. Nishida et al., "Comparison of transcranial doppler investigation of aneurysmal vasospasm with digital subtraction angiographic and clinical findings," Neurosurgery, vol. 45, no. 3, pp. 443-450, 1999.

[48] H. White and B. Venkatesh, "Applications of transcranial Doppler in the ICU: a review," Intensive Care Medicine, vol. 32, no. 7, pp. 981-994, 2006.

[49] C. Lysakowski, B. Walder, M. C. Costanza, and M. R. Tramèr, "Transcranial Doppler versus angiography in patients with vasospasm due to a ruptured cerebral aneurysm: a systematic review," Stroke, vol. 32, no. 10, pp. 2292-2298, 2001.

[50] M. A. Sloan, E. C. Haley Jr., N. F. Kassel et al., "Sensitivity and specificity of transcranial Doppler ultrasonography in the diagnosis of vasospasm following subarachnoid hemorrhage," Neurology, vol. 39, no. 11, pp. 1514-1518, 1989.

[51] X. Liu-DeRyke and D. H. Rhoney, "Cerebral vasospasm after aneurysmal subarachnoid hemorrhage: an overview of pharmacologic management," Pharmacotherapy, vol. 26, no. 2, pp. 182203, 2006.

[52] J. N. Walton, "The prognosis and management of subarachnoid haemorrhage," Canadian Medical Association Journal, vol. 72, no. 3, pp. 165-175, 1955.

[53] P. Rousseaux, B. Scherpereel, M. H. Bernard, J. P. Graftieaux, and J. F. Guyot, "Fever and cerebral vasospasm in ruptured intracranial aneurysms," Surgical Neurology, vol. 14, no. 6, pp. 459-465, 1980.

[54] A. Spallone, M. Acqui, F. S. Pastore, and B. Guidetti, "Relationship between leukocytosis and ischemic complications following aneurysmal subarachnoid hemorrhage," Surgical Neurology, vol. 27, no. 3, pp. 253-258, 1987.

[55] G. Pradilla, K. L. Chaichana, S. Hoang, J. Huang, and R. J. Tamargo, "Inflammation and cerebral vasospasm after subarachnoid hemorrhage," Neurosurgery Clinics of North America, vol. 21, no. 2, pp. 365-379, 2010.

[56] K. L. Chaichana, G. Pradilla, J. Huang, and R. J. Tamargo, "Role of inflammation (leukocyte-endothelial cell interactions) in vasospasm after subarachnoid hemorrhage," World Neurosurgery, vol. 73, no. 1, pp. 22-41, 2010.

[57] D. H. Edwards, J. V. Byrne, and T. M. Griffith, "The effect of chronic subarachnoid hemorrhage on basal endotheliumderived relaxing factor activity in intrathecal cerebral arteries," Journal of Neurosurgery, vol. 76, no. 5, pp. 830-837, 1992.

[58] A. Agil, C. J. Fuller, and I. Jialal, "Susceptibility of plasma to ferrous iron/hydrogen peroxide-mediated oxidation: demonstration of a possible Fenton reaction," Clinical Chemistry, vol. 41, no. 2, pp. 220-225, 1995.

[59] T. M. Griffith, D. H. Edwards, M. J. Lewis, A. C. Newby, and A. H. Henderson, "The nature of endothelium-derived vascular relaxant factor," Nature, vol. 308, no. 5960, pp. 645-647, 1984.

[60] J. M. C. Gutteridge, "Lipid peroxidation and antioxidants as biomarkers of tissue damage," Clinical Chemistry, vol. 41, no. 12, pp. 1819-1828, 1995. 
[61] A. G. Kolias, J. Sen, and A. Belli, "Pathogenesis of cerebral vasospasm following aneurysmal subarachnoid hemorrhage: putative mechanisms and novel approaches," Journal of Neuroscience Research, vol. 87, no. 1, pp. 1-11, 2009.

[62] R. E. Ayer and J. H. Zhang, "Oxidative stress in subarachnoid haemorrhage: significance in acute brain injury and vasospasm," Acta Neurochirurgica, Supplementum, no. 104, pp. 33-41, 2008.

[63] Y. Maeda, K. Hirano, J. Nishimura, T. Sasaki, and H. Kanaide, "Endothelial dysfunction and altered bradykinin response due to oxidative stress induced by serum deprivation in the bovine cerebral artery," European Journal of Pharmacology, vol. 491, no. 1, pp. 53-60, 2004.

[64] J. J. Provencio and N. Vora, "Subarachnoid hemorrhage and inflammation: bench to bedside and back," Seminars in Neurology, vol. 25, no. 4, pp. 435-444, 2005.

[65] K. L. Chaichana, A. P. Levy, R. Miller-Lotan, S. Shakur, and R. J. Tamargo, "Haptoglobin 2-2 genotype determines chronic vasospasm after experimental subarachnoid hemorrhage," Stroke, vol. 38, no. 12, pp. 3266-3271, 2007.

[66] C.-L. Lin, A.-L. Kwan, A. S. Dumont et al., "Attenuation of experimental subarachnoid hemorrhage-induced increases in circulating intercellular adhesion molecule-1 and cerebral vasospasm by the endothelin-converting enzyme inhibitor CGS 26303," Journal of Neurosurgery, vol. 106, no. 3, pp. 442-448, 2007.

[67] C.-L. Lin, A. S. Dumont, T. Calisaneller, A.-L. Kwan, S.L. Hwong, and K. S. Lee, "Monoclonal antibody against E selectin attenuates subarachnoid hemorrhage-induced cerebral vasospasm," Surgical Neurology, vol. 64, no. 3, pp. 201-206, 2005.

[68] H. Jędrzejowska-Szypułka, M. Larysz-Brysz, M. Kukla, M. Śnietura, and J. Lewin-Kowalik, "Neutralization of interleukin$1 \beta$ reduces vasospasm and alters cerebral blood vessel density following experimental subarachnoid hemorrhage in rats," Current Neurovascular Research, vol. 6, no. 2, pp. 95-103, 2009.

[69] G. Chen, J. Wu, C. Sun et al., "Potential role of JAK2 in cerebral vasospasm after experimental subarachnoid hemorrhage," Brain Research, vol. 1214, pp. 136-144, 2008.

[70] G. Bowman, R. H. Bonneau, V. M. Chinchilli, K. J. Tracey, and K. M. Cockroft, "A novel inhibitor of inflammatory cytokine production (CNI-1493) reduces rodent post-hemorrhagic vasospasm," Neurocritical Care, vol. 5, no. 3, pp. 222-229, 2006.

[71] H. Yatsushige, M. Yamaguchi, C. Zhou, J. W. Calvert, and J. H. Zhang, "Role of c-Jun N-terminal kinase in cerebral vasospasm after experimental subarachnoid hemorrhage," Stroke, vol. 36, no. 7, pp. 1538-1543, 2005.

[72] W. A. Muller, "Mechanisms of leukocyte transendothelial migration," Annual Review of Pathology, vol. 6, pp. 323-344, 2011.

[73] Y. Iigo, M. Suematsu, T. Higashida et al., "Constitutive expression of ICAM-1 in rat microvascular systems analyzed by laser confocal microscopy," American Journal of Physiology, vol. 273, no. 1, part 2, pp. H138-H147, 1997.

[74] C. L. Klein, F. Bittinger, H. Kohler et al., "Comparative studies on vascular endothelium in vitro: 3. Effects of cytokines on the expression of E-Selectin, ICAM-1 and VCAM-1 by cultured human endothelial cells obtained from different passages," Pathobiology, vol. 63, no. 2, pp. 83-92, 1995.

[75] D. Scholz, B. Devaux, A. Hirche et al., "Expression of adhesion molecules is specific and time-dependent in cytokinestimulated endothelial cells in culture," Cell and Tissue Research, vol. 284, no. 3, pp. 415-423, 1996.
[76] Y. Hirashima, S. Nakamura, S. Endo, N. Kuwayama, Y. Naruse, and A. Takaku, "Elevation of platelet activating factor, inflammatory cytokines, and coagulation factors in the internal jugular vein of patients with subarachnoid hemorrhage," Neurochemical Research, vol. 22, no. 10, pp. 1249-1255, 1997.

[77] K. Fassbender, B. Hodapp, S. Rossol et al., "Inflammatory cytokines in subarachnoid haemorrhage: association with abnormal blood flow velocities in basal cerebral arteries," Journal of Neurology Neurosurgery and Psychiatry, vol. 70, no. 4, pp. 534-537, 2001.

[78] C. Muroi, J. K. Burkhardt, M. Hugelshofer, M. Seule, K. Mishima, and E. Keller, "Magnesium and the inflammatory response: potential pathophysiological implications in the management of patients with aneurysmal subarachnoid hemorrhage?" Magnesium Research, vol. 25, no. 2, pp. 64-71, 2012.

[79] W. Ni, Y. X. Gu, D. L. Song, B. Leng, P. L. Li, and Y. Mao, “The relationship between IL-6 in CSF and occurrence of vasospasm after subarachnoid hemorrhage," Acta Neurochirurgica. Supplement, vol. 110, no. 1, pp. 203-208, 2011.

[80] S. Hendryk, B. Jarzab, and J. Josko, "Increase of the IL-1 $\beta$ and IL6 levels in CSF in patients with vasospasm following aneurysmal SAH," Neuroendocrinology Letters, vol. 25, no. 1-2, pp. 141-147, 2004.

[81] T. Mathieson, G. Edner, E. Ulfarsson, and B. Andersson, "Cerebrospinal fluid interleukin-1 receptor antagonist and tumor necrosis factor- $\alpha$ following subarachnoid hemorrhage," Journal of Neurosurgery, vol. 87, no. 2, pp. 215-220, 1997.

[82] A. Sarrafzadeh, F. Schlenk, C. Gericke, and P. Vajkoczy, "Relevance of cerebral interleukin-6 after aneurysmal subarachnoid hemorrhage," Neurocritical Care, vol. 13, no. 3, pp. 339-346, 2010.

[83] R. D. Rothoerl, C. Axmann, A.-L. Pina, C. Woertgen, and A. Brawanski, "Possible role of the C-reactive protein and white blood cell count in the pathogenesis of cerebral vasospasm following aneurysmal subarachnoid hemorrhage," Journal of Neurosurgical Anesthesiology, vol. 18, no. 1, pp. 68-72, 2006.

[84] D. Parkinson and S. Stephensen, "Leukocytosis and subarachnoid hemorrhage," Surgical Neurology, vol. 21, no. 2, pp. 132-134, 1984.

[85] M. R. Crompton, "The pathogenesis of cerebral infarction following the rupture of cerebral berry aneurysms," Brain, vol. 87, no. 3, pp. 491-510, 1964.

[86] J. T. Hughes and P. M. Schianchi, "Cerebral artery spasm. A histological study at necropsy of the blood vessels in cases of subarachnoid hemorrhage," Journal of Neurosurgery, vol. 48, no. 4, pp. 515-525, 1978.

[87] A. T. Fraticelli, B. P. Cholley, M.-R. Losser, J.-P. S. Maurice, and D. Payen, "Milrinone for the treatment of cerebral vasospasm after aneurysmal subarachnoid hemorrhage," Stroke, vol. 39, no. 3, pp. 893-898, 2008.

[88] A. Biondi, G. K. Ricciardi, L. Puybasset et al., "Intraarterial nimodipine for the treatment of symptomatic cerebral vasospasm after aneurysmal subarachnoid hemorrhage: preliminary results," American Journal of Neuroradiology, vol. 25, no. 6, pp. 1067-1076, 2004.

[89] A. R. Fathi, R. M. Pluta, K. D. Bakhtian, M. Qi, and R. R. Lonser, "Reversal of cerebral vasospasm via intravenous sodium nitrite after subarachnoid hemorrhage in primates: laboratory investigation," Journal of Neurosurgery, vol. 115, no. 6, pp. 12131220, 2011.

[90] B. P. Thampatty, P. R. Sherwood, M. J. Gallek et al., "Role of Endothelin-1 in human aneurysmal subarachnoid hemorrhage: 
associations with vasospasm and delayed cerebral ischemia," Neurocritical Care, vol. 15, no. 1, pp. 19-27, 2011.

[91] T. Asano, I. Ikegaki, Y. Suzuki, S. Satoh, and M. Shibuya, "Endothelin and the production of cerebral vasospasm in dogs," Biochemical and Biophysical Research Communications, vol. 159, no. 3, pp. 1345-1351, 1989.

[92] M. Zimmermann and V. Seifert, "Endothelin receptor antagonists and cerebral vasospasm," Clinical Autonomic Research, vol. 14, no. 3, pp. 143-145, 2004.

[93] E. Thorin, T.-D. Nguyen, and A. Bouthillier, "Control of vascular tone by endogenous endothelin-1 in human pial arteries," Stroke, vol. 29, no. 1, pp. 175-180, 1998.

[94] K. Bian and F. Murad, "Nitric oxide (NO)-biogeneration, regulation, and relevence to human diseases," Frontiers in Bioscience, vol. 8, pp. d264-d278, 2003.

[95] L. Mascia, L. Fedorko, D. J. Stewart et al., “Temporal relationship between endothelin-1 concentrations and cerebral vasospasm in patients with aneurysmal subarachnoid hemorrhage," Stroke, vol. 32, no. 5, pp. 1185-1189, 2001.

[96] A.-L. Kwan, N. J. Solenski, N. F. Kassell, and K. S. Lee, "Inhibition of nitric oxide generation and lipid peroxidation attenuates hemolysate-induced injury to cerebrovascular endothelium," Acta Neurochirurgica, vol. 139, no. 3, pp. 240-248, 1997.

[97] R. M. Pluta, B. G. Thompson, T. M. Dawson, S. H. Snyder, R. J. Boock, and E. H. Oldfield, "Loss of nitric oxide synthase immunoreactivity in cerebral vasospasm," Journal of Neurosurgery, vol. 84, no. 4, pp. 648-654, 1996.

[98] B. A. Iuliano, R. M. Pluta, C. Jung, and E. H. Oldfield, "Endothelial dysfunction in a primate model of cerebral vasospasm," Journal of Neurosurgery, vol. 100, no. 2, pp. 287-294, 2004.

[99] R. M. Pluta, J. K. B. Afshar, R. J. Boock, and E. H. Oldfield, "Temporal changes in perivascular concentrations of oxyhemoglobin, deoxyhemoglobin, and methemoglobin after subarachnoid hemorrhage," Journal of Neurosurgery, vol. 88, no. 3, pp. 557-561, 1998.

[100] J. W. Peterson, S. Nishizawa, J. D. Hackett, T. Bun, A. Teramura, and N. T. Zervas, "Cyclosporine A reduces cerebral vasospasm after subarachnoid hemorrhage in dogs," Stroke, vol. 21, no. 1, pp. 133-137, 1990.

[101] L. Fei and F. Golwa, "Topical application of dexamethasone to prevent cerebral vasospasm after aneurysmal subarachnoid haemorrhage: a pilot study," Clinical Drug Investigation, vol. 27, no. 12, pp. 827-832, 2007.

[102] K. Nagata, T. Sasaki, J. Iwama et al., "Failure of FK-506, a new immunosuppressant, to prevent cerebral vasospasm in a canine two-hemorrhage model," Journal of Neurosurgery, vol. 79, no. 5, pp. 710-715, 1993.

[103] N. Minami, E. Tani, M. Yokota, Y. Maeda, and I. Yamaura, "Immunohistochemistry of leukotriene $\mathrm{C} 4$ in experimental cerebral vasospasm," Acta Neuropathologica, vol. 81, no. 4, pp. 401-407, 1991.

[104] T. Sugawara, R. Ayer, V. Jadhav, W. Chen, T. Tsubokawa, and J. H. Zhang, "Mechanisms of statin treatment in cerebral vasospasm," Acta neurochirurgica. Supplement, vol. 110, no. 2, part 2, pp. 9-11, 2011.

[105] J. R. Lynch, H. Wang, M. J. McGirt et al., "Simvastatin reduces vasospasm after aneurysmal subarachnoid hemorrhage: results of a pilot randomized clinical trial," Stroke, vol. 36, no. 9, pp. 2024-2026, 2005.

[106] J. L. Trimble and D. R. Kockler, "Statin treatment of cerebral vasospasm after aneurysmal subarachnoid hemorrhage," Annals of Pharmacotherapy, vol. 41, no. 12, pp. 2019-2023, 2007.
[107] G. Bowman, S. Dixit, R. H. Bonneau et al., "Neutralizing antibody against interleukin-6 attenuates posthemorrhagic vasospasm in the rat femoral artery model," Neurosurgery, vol. 54, no. 3, pp. 719-726, 2004.

[108] A. M. Yahia, J. F. Kirmani, A. I. Qureshi, L. R. Guterman, and L. N. Hopkins, "The safety and feasibility of continuous intravenous magnesium sulfate for prevention of cerebral vasospasm in aneurysmal subarachnoid hemorrhage," Neurocritical Care, vol. 3, no. 1, pp. 16-23, 2005.

[109] Q. A. Shah, M. Z. Memon, M. F. K. Suri et al., "Superselective intra-arterial magnesium sulfate in combination with nicardipine for the treatment of cerebral vasospasm in patients with subarachnoid hemorrhage," Neurocritical Care, vol. 11, no. 2, pp. 190-198, 2009.

[110] G. J. Pyne, T. A. D. Cadoux-Hudson, and J. F. Clark, "Magnesium protection against in vitro cerebral vasospasm after subarachnoid haemorrhage," British Journal of Neurosurgery, vol. 15, no. 5, pp. 409-415, 2001.

[111] K. Mori, T. Yamamoto, M. Miyazaki et al., "Effect of intrathecal magnesium sulfate solution injection via a microcatheter in the cisterna magna on cerebral vasospasm in the canine subarachnoid haemorrhage model," British Journal of Neurosurgery, vol. 26, no. 1, pp. 64-68, 2012.

[112] J. S. Jeon, S. H. Sheen, G. Hwang, S. H. Kang, D. H. Heo, and Y. J. Cho, "Intravenous magnesium infusion for the prevention of symptomatic cerebral vasospasm after aneurysmal subarachnoid hemorrhage," Journal of Korean Neurosurgical Society, vol. 52, no. 2, pp. 75-79, 2012.

[113] B. T. Altura and B. M. Altura, "Withdrawal of magnesium causes vasospasm while elevated magnesium produces relaxation of tone in cerebral arteries," Neuroscience Letters, vol. 20, no. 3, pp. 323-327, 1980.

[114] R. L. Macdonald, R. T. Higashida, E. Keller et al., "Clazosentan, an endothelin receptor antagonist, in patients with aneurysmal subarachnoid haemorrhage undergoing surgical clipping: a randomised, double-blind, placebo-controlled phase 3 trial (CONSCIOUS-2)," The Lancet Neurology, vol. 10, no. 7, pp. 618$625,2011$.

[115] Y. Hong, S. Guo, S. Chen, C. Sun, J. Zhang, and X. Sun, "Beneficial effect of hydrogen-rich saline on cerebral vasospasm after experimental subarachnoid hemorrhage in rats," Journal of Neuroscience Research, vol. 90, no. 8, pp. 1670-1680, 2012.

[116] M. Lim, R. S. Bower, Y. Wang et al., "The predictive value of serum myeloperoxidase for vasospasm in patients with aneurysmal subarachnoid hemorrhage," Neurosurgical Review, vol. 35, no. 3, pp. 413-419, 2012.

[117] Z. Prokopowicz, J. Marcinkiewicz, D. R. Katz, and B. M. Chain, "Neutrophil myeloperoxidase: soldier and statesman," Archivum Immunologiae et Therapiae Experimentalis, vol. 60, no. 1, pp. 43-54, 2012.

[118] J. A. Frontera, A. Fernandez, J. M. Schmidt et al., "Defining vasospasm after subarachnoid hemorrhage: what is the most clinically relevant definition?" Stroke, vol. 40, no. 6, pp. 19631968, 2009.

[119] P. M. Meyers and E. S. Connolly Jr., "Stroke: disappointing results for clazosentan in CONSCIOUS-2," Nature Reviews Neurology, vol. 7, no. 12, pp. 660-661, 2011.

[120] J. Hansen-Schwartz, P. Vajkoczy, R. L. Macdonald, R. M. Pluta, and J. H. Zhang, "Cerebral vasospasm: looking beyond vasoconstriction," Trends in Pharmacological Sciences, vol. 28, no. 6, pp. 252-256, 2007. 
[121] L. Z. Leng, M. E. Fink, and C. Iadecola, "Spreading depolarization: a possible new culprit in the delayed cerebral ischemia of subarachnoid hemorrhage," Archives of Neurology, vol. 68, no. 1, pp. 31-36, 2011.

[122] C. Muroi, M. Seule, K. Mishima, and E. Keller, "Novel treatments for vasospasm after subarachnoid hemorrhage," Current Opinion in Critical Care, vol. 18, no. 2, pp. 119-126, 2012.

[123] M. D. I. Vergouwen, M. Vermeulen, B. A. Coert, E. S. G. Stroes, and Y. B. W. E. M. Roos, "Microthrombosis after aneurysmal subarachnoid hemorrhage: an additional explanation for delayed cerebral ischemia," Journal of Cerebral Blood Flow and Metabolism, vol. 28, no. 11, pp. 1761-1770, 2008.

[124] M. J. Rowland, G. Hadjipavlou, M. Kelly, J. Westbrook, and K. T. Pattinson, "Delayed cerebral ischaemia after subarachnoid haemorrhage: looking beyond vasospasm," British Journal of Anaesthesia, vol. 109, no. 3, pp. 315-329, 2012.

[125] J. Claassen, J. R. Carhuapoma, K. T. Kreiter, E. Y. Du, E. S. Connolly, and S. A. Mayer, "Global cerebral edema after subarachnoid hemorrhage: frequency, predictors, and impact on outcome," Stroke, vol. 33, no. 5, pp. 1225-1232, 2002.

[126] H. Nornes, "The role of intracranial pressure in the arrest of hemorrhage in patients with ruptured intracranial aneurysm," Journal of Neurosurgery, vol. 39, no. 2, pp. 226-234, 1973.

[127] E. Grote and W. Hassler, "The critical first minutes after subarachnoid hemorrhage," Neurosurgery, vol. 22, no. 4, pp. 654-661, 1988.

[128] T. Rätsep and T. Asser, "Cerebral hemodynamic impairment after aneurysmal subarachnoid hemorrhage as evaluated using transcranial Doppler ultrasonography: relationship to delayed cerebral ischemia and clinical outcome," Journal of Neurosurgery, vol. 95, no. 3, pp. 393-401, 2001.

[129] J. P. Dreier, J. Woitzik, M. Fabricius et al., "Delayed ischaemic neurological deficits after subarachnoid haemorrhage are associated with clusters of spreading depolarizations," Brain, vol. 129, no. 12, pp. 3224-3237, 2006.

[130] J. P. Dreier, S. Major, A. Manning et al., "Cortical spreading ischaemia is a novel process involved in ischaemic damage in patients with aneurysmal subarachnoid haemorrhage," Brain, vol. 132, no. 7, pp. 1866-1881, 2009.

[131] C. J. M. Frijns, R. Fijnheer, A. Algra, J. A. Van Mourik, J. Van Gijn, and G. J. E. Rinkel, "Early circulating levels of endothelial cell activation markers in aneurysmal subarachnoid haemorrhage: associations with cerebral ischaemic events and outcome," Journal of Neurology, Neurosurgery and Psychiatry, vol. 77, no. 1, pp. 77-83, 2006.

[132] S. Suzuki, M. Kimura, M. Souma, H. Ohkima, T. Iwabuchi, and T. Shimiz u, "Cerebral microthrombosis in symptomatic cerebral vasospasm - a quantitative histological study in autopsy cases," Neurologia Medico-Chirurgica, vol. 30, no. 5, pp. 309-316, 1990.

[133] J. G. Romano, A. M. Forteza, M. Concha et al., "Detection of microemboli by transcranial Doppler ultrasonography in aneurysmal subarachnoid hemorrhage," Neurosurgery, vol. 50, no. 5, pp. 1026-1031, 2002.

[134] Y. Z. Al-Tamimi, D. Bhargava, R. G. Feltbower et al., "Lumbar drainage of cerebrospinal fluid after aneurysmal subarachnoid hemorrhage: a prospective, randomized, controlled trial (LUMAS)," Stroke, vol. 43, no. 3, pp. 677-682, 2012.
[135] J. Bardutzky, J. Witsch, E. Jüttler, S. Schwab, P. Vajkoczy, and S. Wolf, "EARLYDRAIN-outcome after early lumbar CSFdrainage in aneurysmal subarachnoid hemorrhage: study protocol for a randomized controlled trial," Trials, vol. 12, article 203, 2011.

[136] D. Hänggi, S. Eicker, K. Beseoglu, J. Behr, B. Turowski, and H.-J. Steiger, "A multimodal concept in patients after severe aneurysmal subarachnoid hemorrhage: results of a controlled single centre prospective randomized multimodal phase I/II trial on cerebral vasospasm," Zentralblatt fur Neurochirurgie, vol. 70, no. 2, pp. 61-67, 2009.

[137] T. Mathiesen, D. Fuchs, H. Wachter, and H. von Holst, "Increased CSF neopterin levels in subarachnoid hemorrhage," Journal of Neurosurgery, vol. 73, no. 1, pp. 69-71, 1990.

[138] J. W. Peterson, B.-D. Kwun, J. D. Hackett, and N. T. Zervas, "The role of inflammation in experimental cerebral vasospasm," Journal of Neurosurgery, vol. 72, no. 5, pp. 767-774, 1990.

[139] H. Onda, H. Kasuya, K. Takakura et al., "Identification of genes differentially expressed in canine vasospastic cerebral arteries after subarachnoid hemorrhage," Journal of Cerebral Blood Flow and Metabolism, vol. 19, no. 11, pp. 1279-1288, 1999.

[140] Y. Aihara, H. Kasuya, H. Onda, T. Hori, and J. Takeda, "Quantitative analysis of gene expressions related to inflammation in canine spastic artery after subarachnoid hemorrhage," Stroke, vol. 32, no. 1, pp. 212-217, 2001.

[141] M. J. McGirt, J. R. Lynch, R. Blessing et al., "Serum von Willebrand factor, matrix metalloproteinase-9, and vascular endothelial growth factor levels predict the onset of cerebral vasospasm after aneurysmal subarachnoid hemorrhage," Neurosurgery, vol. 51, no. 5, pp. 1128-1135, 2002.

[142] T. Sasaki, H. Kasuya, H. Onda et al., "Role of p38 mitogenactivated protein kinase on cerebral vasospasm after subarachnoid hemorrhage," Stroke, vol. 35, no. 6, pp. 1466-1470, 2004.

[143] M.-L. Zhou, J.-X. Shi, C.-H. Hang et al., "Potential contribution of nuclear factor- $\kappa \mathrm{B}$ to cerebral vasospasm after experimental subarachnoid hemorrhage in rabbits," Journal of Cerebral Blood Flow and Metabolism, vol. 27, no. 9, pp. 1583-1592, 2007.

[144] Z. Wang, K.-Y. Wang, Y. Wu, P. Zhou, X.-O. Sun, and G. Chen, "Potential role of CD34 in cerebral vasospasm after experimental subarachnoid hemorrhage in rats," Cytokine, vol. 52, no. 3, pp. 245-251, 2010.

[145] C. Wirrig, I. Hunter, F. A. Mathieson, and G. F. Nixon, "Sphingosylphosphorylcholine is a proinflammatory mediator in cerebral arteries," Journal of Cerebral Blood Flow \& Metabolism, vol. 31, no. 1, pp. 212-221, 2011.

[146] K. Tokiyoshi, T. Ohnishi, and Y. Nii, "Efficacy and toxicity of thromboxane synthetase inhibitor for cerebral vasospasm after subarachnoid hemorrhage," Surgical Neurology, vol. 36, no. 2, pp. 112-118, 1991.

[147] K. Iseda, S. Ono, K. Onoda et al., "Antivasospastic and antiinflammatory effects of caspase inhibitor in experimental subarachnoid hemorrhage," Journal of Neurosurgery, vol. 107, no. 1, pp. 128-135, 2007.

[148] T. Yoshimoto, T. Shirasaka, S. Fujimoto et al., "Cilostazol may prevent cerebral vasospasm following subarachnoid hemorrhage," Neurologia Medico-Chirurgica, vol. 49, no. 6, pp. 235240, 2009.

[149] Y. Wu, X.-D. Zhao, Z. Zhuang et al., "Peroxisome proliferatoractivated receptor gamma agonist rosiglitazone attenuates oxyhemoglobin-induced Toll-like receptor 4 expression in vascular smooth muscle cells," Brain Research, vol. 1322, pp. 102$108,2010$. 
[150] C.-Z. Chang, C.-L. Lin, N. F. Kassel, A.-L. Kwan, and S.-L. Howng, "6-mercaptopurine attenuates adhesive molecules in experimental vasospasm," Acta Neurochirurgica, vol. 152, no. 5, pp. 861-867, 2010.

[151] S. Muehlschlegel, G. Rordorf, and J. Sims, "Effects of a single dose of dantrolene in patients with cerebral vasospasm after subarachnoid hemorrhage: a prospective pilot study," Stroke, vol. 42, no. 5, pp. 1301-1306, 2011.

[152] W. Zhang, N. H. Khatibi, M. Yamaguchi-Okada et al., "Mammalian target of rapamycin (mTOR) inhibition reduces cerebral vasospasm following a subarachnoid hemorrhage injury in canines," Experimental Neurology, vol. 233, no. 2, pp. 799-806, 2012. 


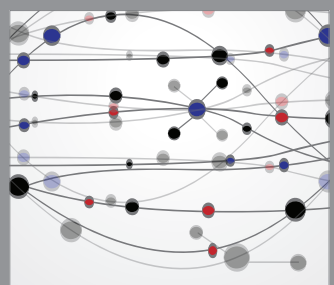

The Scientific World Journal
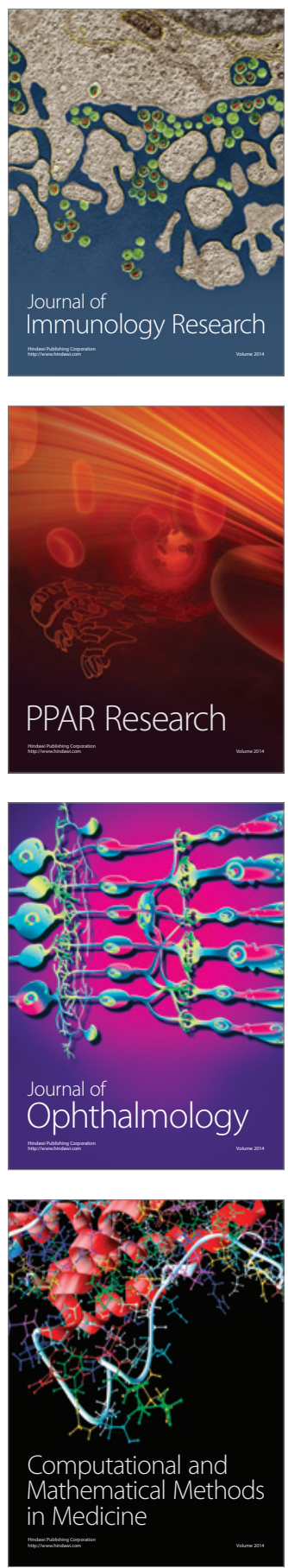

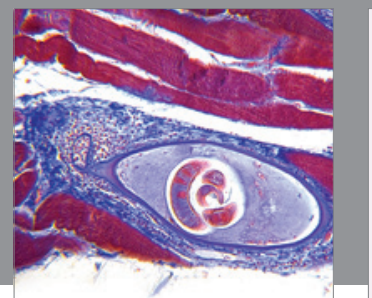

Gastroenterology

Research and Practice
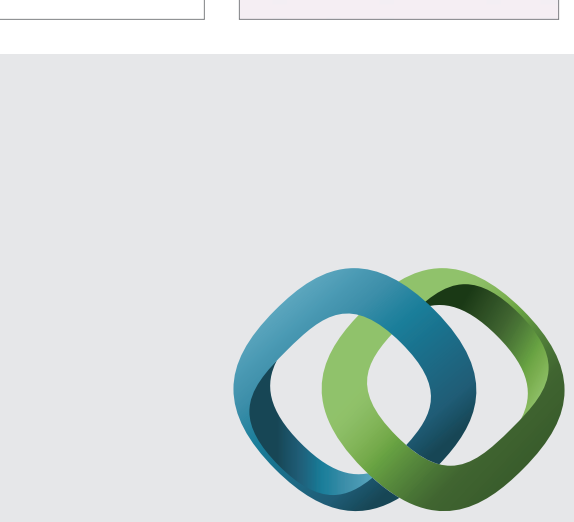

\section{Hindawi}

Submit your manuscripts at

http://www.hindawi.com
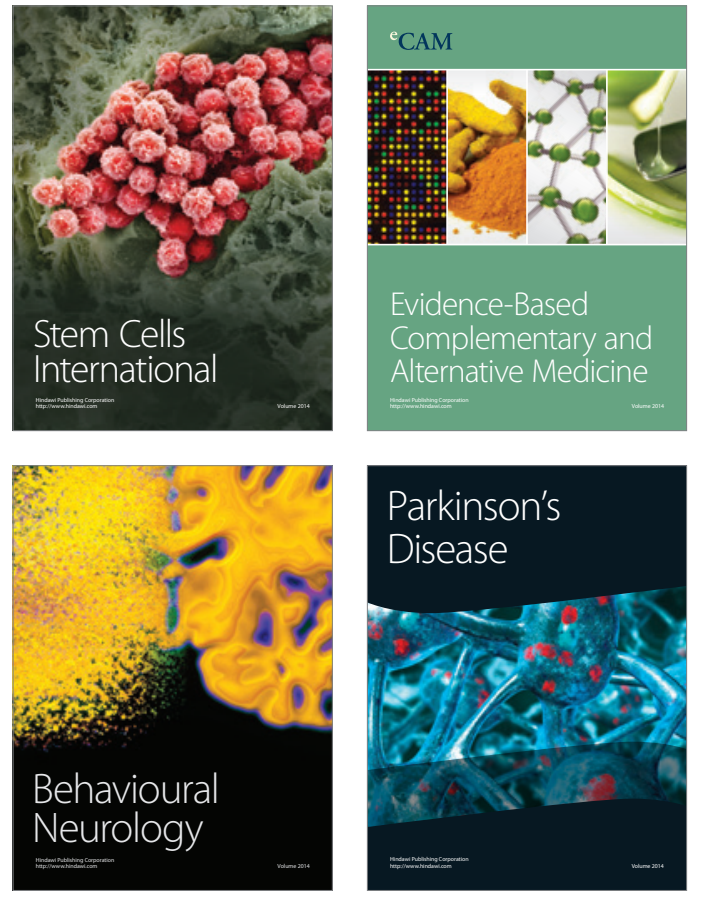
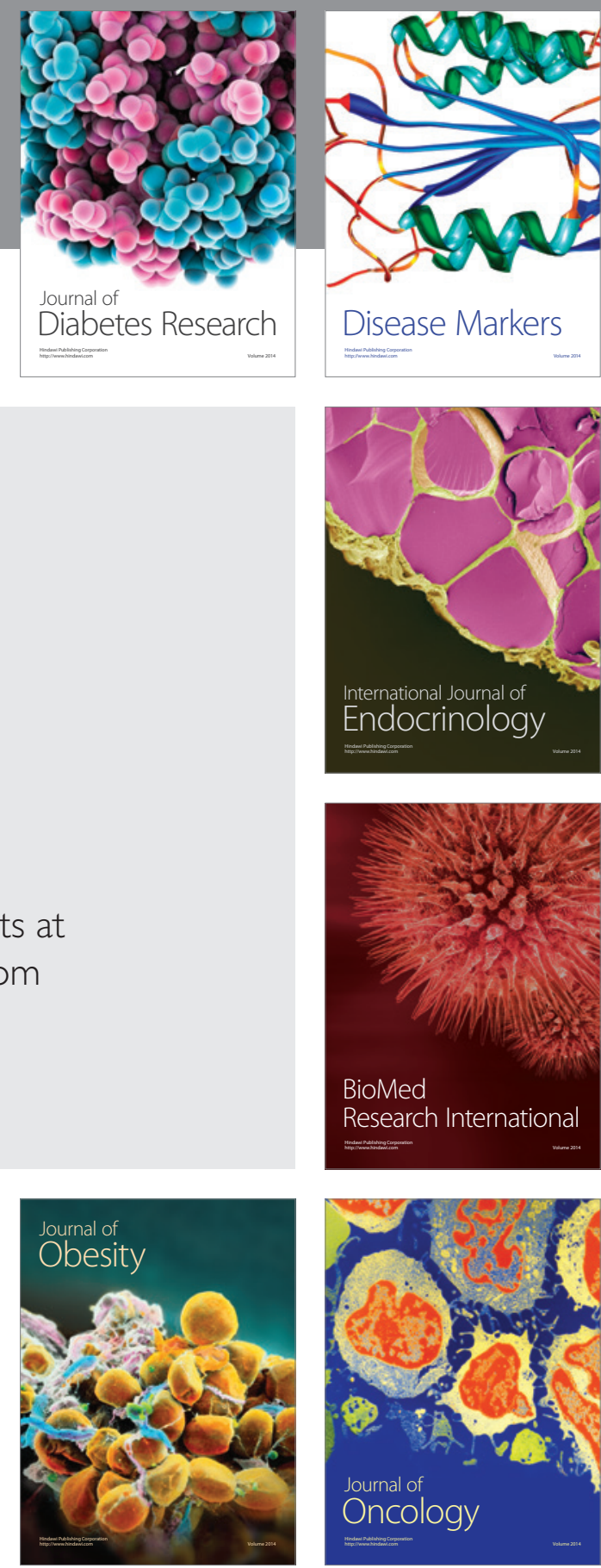

Disease Markers
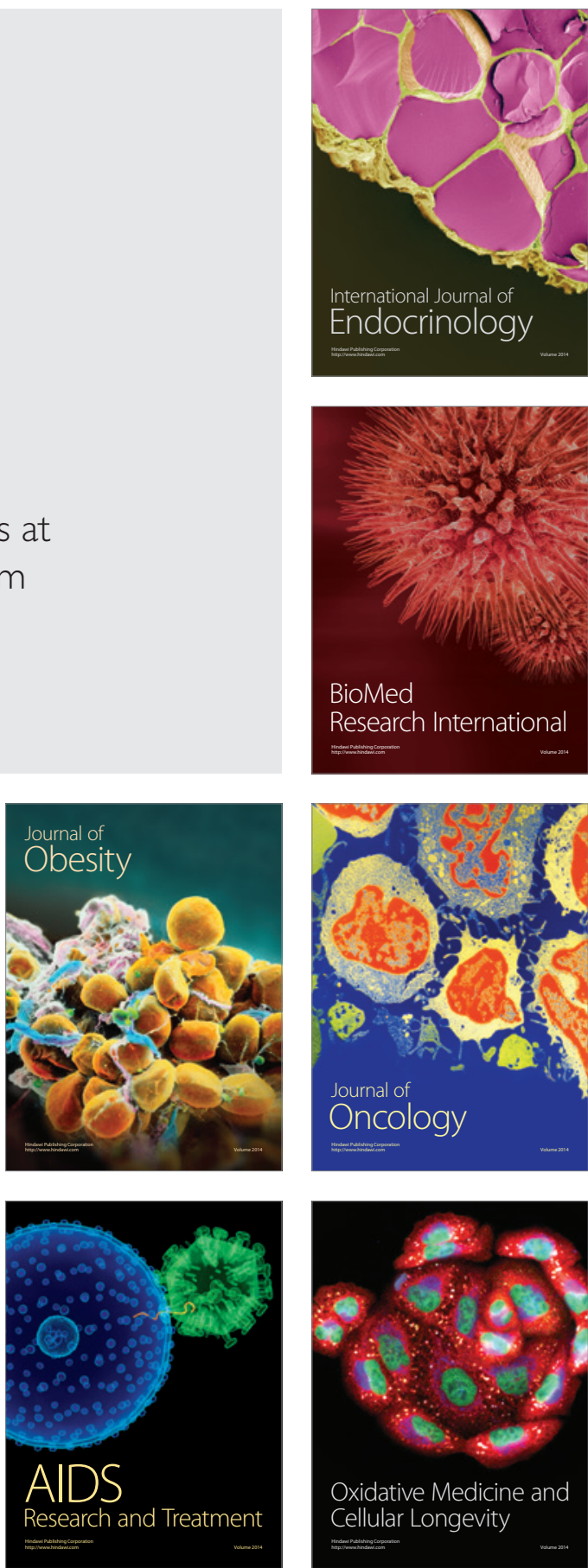